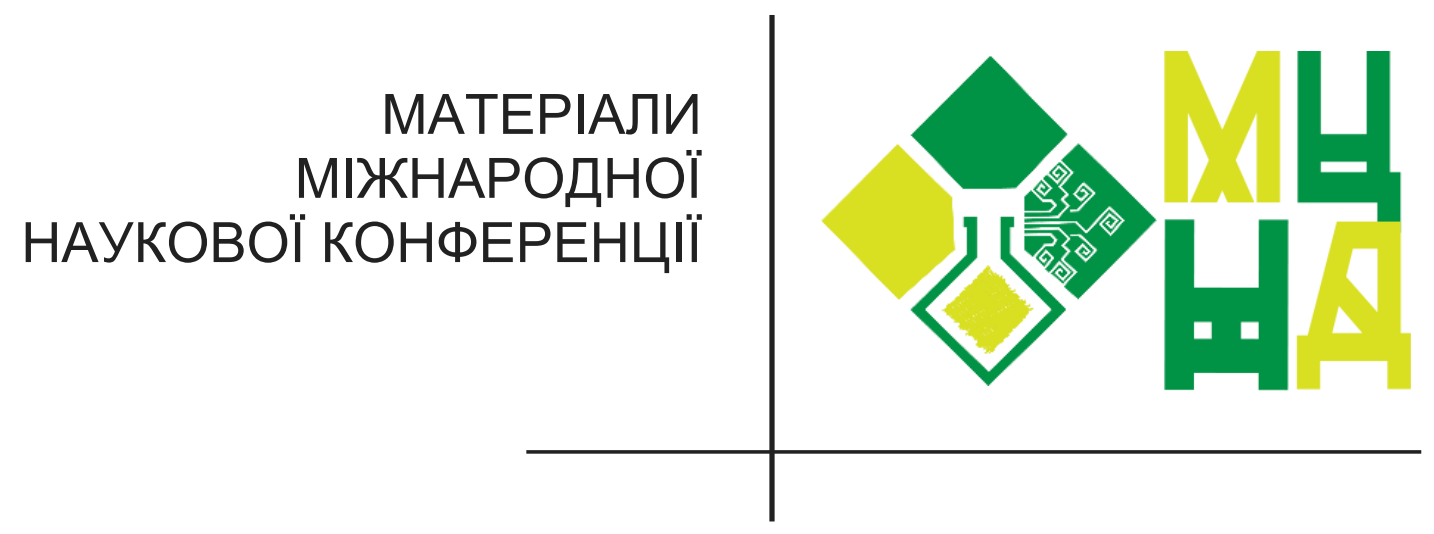

\title{
НАУКОВИЙ ПРОЦЕС ТА НАУКОВІ ПІДХОДИ: МЕТОДИКА ТА РЕАЛІЗАЦІЯ ДОСЛІДЖЕНЬ
}

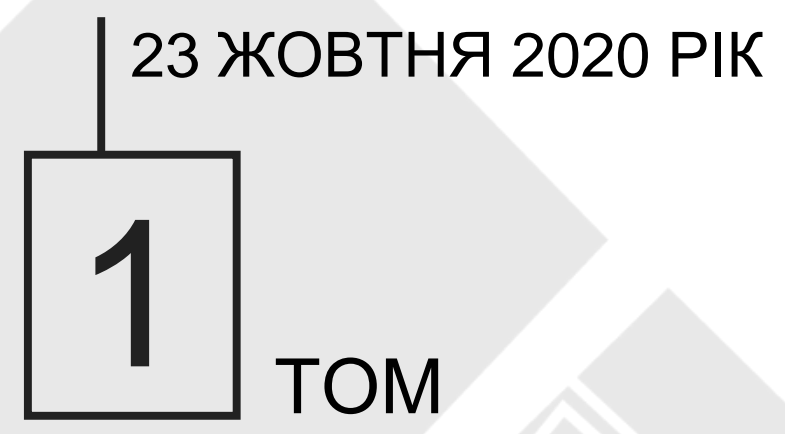

Одеса \ Україна 
Голова оргкомітету: Рабей Н.P.

Верстка: Білоус T.В.

Дизайн: Бондаренко I.B.

Н34 Науковий процес та наукові підходи: методика та реалізація досліджень: матеріали міжнародної наукової конференції (Т. 1), 23 жовтня, 2020 рік. Одеса, Україна: МЦНД.

ISBN 978-617-7171-59-0

DOI 10.36074/23.10.2020.v1

Викладено матеріали учасників міжнародної мультидисциплінарної наукової конференції «Науковий процес та наукові підходи: методика та реалізація досліджень», яка відбулася у місті Одеса 23 жовтня 2020 року.

Конференцію зареєстровано Державною науковою установою «УкрIHTEI» в базі даних науково-технічних заходів України та інформаційному бюлетені «План проведення наукових, науково-технічних заходів в Україні» (Посвідчення № 447 від 05.10.2020).

Матеріали конфреренції знаходяться у відкритому доступі на умовах ліцензії Creative Commons Attribution 4.0 International (CC BY 4.0).

Всі роботи збірника відображені в Google Scholar. Роботи, що містять иифровий ідентифрікатор DOI індексуються в ORCID, CrossRef ma OUCl (Український індекс наукового цитування).

УДК 001 (08)

() Колектив учасників конференції, 2020

ISBN 978-617-7171-59-0 С Міжнародний центр наукових досліджень, 2020 


\section{MICT}

\section{СЕКЦІЯ I. ЕКОНОМІЧНІ НАУКИ}

ВИДИ БАР'ЄРІВ НА ШЛЯХУ ДО ВПРОВАДЖЕННЯ НА ПІДПРИЄМСТВАХ ЗАХОДІВ 3 ЕНЕРГОЗБЕРЕЖЕННЯ ТА РОЛЬ ДЕРЖАВИ У ПОДОЛАННІ ЦИХ БАР'ЄPIB

Петрушка Т.О., Юхман Я.В., Петрушка К.І. .8

ІНФОРМАЦІЙНА АСИМЕТРІЯ I НЕВИЗНАЧЕНІСТЬ НА ФІНАНСОВИХ РИНКАХ Захарченко В.І., Мельниченко Д.О.

МЕТОДОЛОГІЧНІ ЗАСАДИ ОЦІНЮВАННЯ ФІНАНСОВО-ЕКОНОМІЧНИХ БАР'ЄРІВ НА ШЛЯХУ ДО ВПРОВАДЖЕННЯ НА ПІДПРИЕМСТВІ ЕНЕРГОЗБЕРІГАЮЧИХ ПРОЕКТІВ

Ємельянов О.Ю.

МЕХАНІЗМИ ВПЛИВУ РЕАЛІЗАЦІЇ ІНВЕСТИЦІЙНИХ ПРОЕКТІВ 3 ЕНЕРГОЗБЕРЕЖЕННЯ НА ФІНАНСОВИЙ СТАН ПІДПРИЕМСТВ

Соколенко В.В,, Ємельянов О.Ю.

ПИТАННЯ РЕФОРМУВАННЯ СИСТЕМИ ДЕРЖАВНОГО ФІНАНСОВОГО КОНТРОЛЮ В УКРАЇНІ

Нікуліца Д.Р., Міняйло В.П.

СУТНІСТЬ ПОТЕНЦІАЛУ ПІДВИЩЕННЯ ФІНАНСОВОЇ СТІЙКОСТІ ПІДПРИЕМСТВ ТА ОСОБЛИВОСТІ ЙОГО ОЦІНЮВАННЯ

Ревуцький Я.С., Ємельянов О.Ю.

ФІНАНСОВА СТІЙКІСТЬ КОМЕРЦІЙНОГО БАНКУ: СУТНІСТЬ ТА ФАКТОРИ ВПЛИВУ

Бандура I.A.

ФОРМУВАННЯ ТОРГІВЕЛЬНОГО БАЛАНСУ УКРАЇНИ: ВИКЛИКИ । ПЕРСПЕКТИВИ

Грубінка I.I.

\section{СЕКЦІЯ II.}

СІЛЬСЬКОГОСПОДАРСЬКІ НАУКИ

ДЕТОКСИКАЦІЯ ТА ТРАНСЛОКАЦІЯ ПЕСТИЦИДІВ В РОСЛИНАХ КАРТОПЛІ ТА ГРУНТІ

Адаменко Н.М.

ВИРОЩУВАННЯ І ВИКОРИСТАННЯ У ПОЛЬОВОМУ КОРМОВИРОБНИЦТВІ ЛУЧНОї КОНЮШИНИ

Огородник Н.3., Сусол Н.Е., Сварчевська О.3. 
ПРОДУКТИВНІСТЬ БУГАЙЦІВ З ВИКОРИСТАННЯМ КОРМІВ ЗІ СХОВИЩ В УМОВАХ ЗОНИ КАРПАТ

Калинка А.К.

СУЧАСНИЙ СТАН ВИРОЩУВАННЯ ТА ПОШИРЕННЯ CORYLUS MAXIMА MILL. В УKРAÏHI

Лозінська Т.П., Ярмоленко К.О. 36

\section{СЕКЦІЯ III. ДЕРЖАВНЕ УПРАВЛІННЯ ТА ЕКОЛОГІЯ}

ОСВІТНЯ МІГРАЦІЯ - ЧИННИК СТИМУЛЮВАННЯ РОЗВИТКУ ДЕРЖАВИ

Мосора Л.С.

\section{СЕКЦІЯ IV. \\ ТЕХНІЧНІ НАУКИ ТА ІНФОРМАЦІЙНІ ТЕХНОЛОГІЇ}

INFORMATIZATION AS THE BASIS OF HEI'S ACTIVITIES IN THE PROCESS OF INTERNATIONALIZATION IN THE CONDITIONS OF THE COVID-19 PANDEMIC Shilinh A.Y.

ВИКОРИСТАННЯ ПРОГРАМНИХ ЗАСОБІВ ДЛЯ ПРОГНОЗУВАННЯ ДИНАМІКИ ПАЛИВНИХ РИНКІВ

Семененко О.В.

ЗАСТОСУВАННЯ ІНФОРМАЦІЙНОЇ СИСТЕМИ 3 ОЦІНКИ ЕФЕКТИВНОСТІ КРЕДИТНОГО МЕНЕДЖМЕНТУ

щвець А.Ю.

МЕТАЛЕВИЙ КАРКАС БУДІВЕЛЬ: ПЕРЕВАГИ ТА НЕДОЛІКИ

Костюкова М.O.

МЕТОДИ ПІДВИЩЕННЯ НАДІЙНОСТІ ТА ЕФЕКТИВНОСТІ ВІБРАЦІЙНИХ МАШИН БУДІВЕЛЬНОЇ ІНДУСТРІЇ

Делембовський М.М., Клименко М.О.

ПЕРЕВАГИ ВИКОРИСТАННЯ СИСТЕМИ WРF ДЛЯ СТВОРЕННЯ ПРОГРАМ 3 ГРАФІЧНИМ ІНТЕРФЕЙСОМ

Петренко Д., Вельмагіна Н.

РОЗРОБКА ВЕБ-ДОДАТКУ ДЛЯ СПІЛКУВАННЯ МІЖ КОРИСТУВАЧАМИ 3 ВИКОРИСТАННЯМ КЛІЕНТ-СЕРВЕРНИХ ТЕХНОЛОГІЙ

Гузь Д.В., Пономарьова О.А.

РОЗРОБКА ІНФОРМАЦІЙНОЇ СИСТЕМИ З АНАЛІЗУ РОБОЧОГО СТАНУ СКЛАДНОÏ ТЕХНІЧНОЇ СИСТЕМИ

Рибак М.І., Шибаєва Д.С. 
СИНТЕЗ У ПРОМИСЛОВИХ УМОВАХ ПРИСКОРЮВАЧІВ ВУЛКАНИЗАЦІЇ ТА ТЕРМО- І СВІТЛОСТАБІЛІЗАТОРІВ ДЛЯ РІЗНИХ ВИДІВ ГУМИ ДЛЯ ШИН АВТОМОТОТРАНСПОРТУ

Керемет М.А., Мороз О.В.

ЯКУ ВИБРАТИ ОПЕРАЦІЙНУ СИСТЕМУ ДЛЯ СЕРВЕРІВ?

Максименко А.A.

\section{СЕКЦІЯ V.}

\section{ХІМІЧНІ НАУКИ}

APPROVAL OF ZEOLITE OPERATING CONDITIONS WITH HARRINGTON APPROVAL FUNCTION

Khamroyev J.K.

УЛЬТРАФІОЛЕТОВІ ФІЛЬТРИ ЯК СКЛАДНИКИ СОНЦЕЗАХИСНИХ КОСМЕТИЧНИХ ПРОДУКТІВ

Пилипенко Т.М., Мансурова А.В.

\section{СЕКЦІЯ VI.}

\section{БІОЛОГІЧНІ НАУКИ}

БІОЛОГІЧНИЙ МЕТОД ЗАХИСТУ СІЛЬСЬКОГОСПОДАРСЬКИХ КУЛЬТУР ВІД ХВОРОБ

Куцина С.М.

МЕТОД ВВЕДЕННЯ ДНК В РОСЛИННІ КЛІТИНИ ЗА ДОПОМОГОЮ ВИКОРИСТАННЯ ТІ-ПЛАЗМІД

Куцина С.M.

ОЦІНКА ЯКІСНОГО СКЛАДУ МІКРОМІЦЕТІВ РИЗОСФЕРИ САМОСІВУ QUERCUS ROBUR L. У ПРИРОДНИХ ЛИПОВО-ЯСЕНЕВИХ ЗАПЛАВНИХ ДІБРОВАХ СТЕПОВОГО ПРИДНІПРОВ'Я

Науково-дослідна група:

Іванько І.А., Дрегваль О.А., Скляр Т.В., Кулік А.Ф., Ніколаєва В.В. 77

\section{СЕКЦІЯ VII. МЕДИЧНІ НАУКИ}

ЗВ'ЯЗОК МІЖ ГІПЕРУРИКЕМІЄЮ ТА СТУПЕНЕМ КОМПЕНСАЦІЇ ЦУКРОВОГО ДІАБЕТУ 2-ГО ТИПУ У ПАЦІЄНТІВ ІЗ АРТЕРІАЛЬНОЮ ГІПЕРТЕНЗІЄЮ Волнушкіна Н.Ю.

ШЛЯХИ ВДОСКОНАЛЕННЯ КЛІНІЧНОГО МИСЛЕННЯ В ІНТЕРНАТУРІ 3 ПЕДІАТРІЇ

Мургіна М.М. 


\section{СЕКЦІЯ VIII. \\ BETEPИНАРНI НАУКИ}

ОСОБЛИВОСТІ ЗАСТОСУВАННЯ ІНТЕРАКТИВНИХ ТЕХНОЛОГІЙ У ПРОЦЕСІ НАВЧАННЯ ФАРМАЦЕВТИЧНОЇ ТЕРМІНОЛОГІЇ МАЙБУТНІХ СПЕЦІАЛІСТІВ ВЕТЕРИНАРНОÏ МЕДИЦИНИ

Жванія O.І.

\section{СЕКЦІЯ IX. ПСИХОЛОГІЧНІ ТА СОЦІОЛОГІЧНІ НАУКИ}

АНТИЦИПАЦІЙНІ МЕХАНІЗМИ ТА ПІДХОДИ В СОЦІОГУМАНІТРАНОМУ АСПЕКТІ ПІЗНАННЯ

Чернова М.В., Шилівська І.П.

КОНФЛІКТОЛОГІЧНА КУЛЬТУРА ФАХІВЦІВ ОРГАНІВ МІСЦЕВОГО САМОВРЯДУВАННЯ

Мелентєва І.Б.

ПОСТТРАВМАТИЧНИЙ СТРЕСОВИЙ РОЗЛАД: ОСОБЛИВОСТІ ПСИХОЛОГІЧНОГО СУПРОВОДУ

Ободовська Л.В.

ПСИХОЛОГІЧНІ ОСОБЛИВОСТІ КОНФЛІКТІВ У СТУДЕНТСЬКОМУ СЕРЕДОВИЩІ

Зінченко О.І.

ПСИХОЛОГІЧНІ ОСОБЛИВОСТІ ОРГАНІЗАЦІЇ ДИСТАНЦІЙНОГО НАВЧАННЯ ДЛЯ СТУДЕНТІВ

Ігнатенко Д.Р.

ФОРМУВАННЯ ЕТНІЧНОЇ ІДЕНТИЧНОСТІ СТУДЕНТСЬКОЇ МОЛОДІ

Бабак М.O., Яшник С.В. 99

ФОРМУВАННЯ ПРОФЕСІЙНО-ЦІЛЬОВОЇ РЕФЛЕКСІЇ КЕРІВНИКІВ

Яшник С.В. 101

\section{СЕКЦІЯ $\mathrm{X}$.}

ЮРИДИЧНІ НАУКИ

KOORDINACIONA PRAVNA TEHNOLOGIJA U TRENUTNOM ZAKONODAVSTVU BOSNE I HERCEGOVINE

Maksurov A.A.

ДВОМОВНА ОСВІТА У ПОЛІКУЛЬТУРНОМУ СУСПІЛЬСТВІ

Сопілко Д.В. 
КІБЕРРОЗВІДКА ЯК НОВІТНІЙ НАПРЯМ ОПЕРАТИВНО-РОЗШУКОВОЇ ДІЯЛЬНОСТІ

Козицька О.Г.

НОРМАТИВНО-ПРАВОВЕ РЕГУЛЮВАННЯ В УКРАЇНІ ПИТАННЯ ЗАХИСТУ ПЕРСОНАЛЬНИХ ДАНИХ У СФЕРІ ОХОРОНИ ЗДОРОВ'Я

Худик В.Г.

ОСОБЛИВОСТІ ЕЛЕКТРОННОГО ЦИФРОВОГО ПІДПИСУ У ГОСПОДАРСЬКОМУ ПРОЦЕСІ

Абражевич Д.А.

ОХОРОНА КОНСТИТУЦІЇ У КАНАДІ: ОСОБЛИВОСТІ НОРМАТИВНОГО ЗАКРІПЛЕННЯ ТА ПРАКТИКА РЕАЛІЗАЦІЇ

Пасєчнік Д.В.

СОЦІАЛЬНА ПОЛІТИКА ДЕРЖАВИ ЯК ОСНОВА СОЦІАЛЬНОГО ЗАХИСТУ

Клипа О.П.

СТАНОВЛЕННЯ ТА УТВЕРДЖЕННЯ ПРИНЦИПУ ПРОФЕСІОНАЛІЗМУ В ПУБЛІЧНІЙ СЛУЖБІ УКРАЇНИ

Татоян Д.Л.

СУЧАСНІ ПРОБЛЕМИ ІНТЕЛЕКТУАЛЬНОЇ ВЛАСНОСТІ В УКРАЇНІ

Марченко К.О.

ТЕОРЕТИКО-МЕТОДОЛОГІЧНІ ОСНОВИ ПУБЛІЧНОГО АДМІНІСТРУВАННЯ У СФЕРІ ТУРИСТИЧНОЇ ДІЯЛЬНОСТІ

Дубов С.М.

\section{СЕКЦІЯ XI.}

\section{АРХІТЕКТУРА ТА МИСТЕЦТВОЗНАВСТВО}

КОНЦЕПЦІЯ ВИКЛАДАННЯ ПРЕДМЕТА ІКОНОГРАФІЯ У МИСТЕЦЬКИХ ЗАКЛАДАХ ВИЩОЇ ОСВІТИ

Тимків О.A.

ОКРЕМІ АСПЕКТИ ВИКЛАДАННЯ МОДИФІКОВАНОЇ ТЕХНІКИ ЧОРНО-БІЛОЇ КСИЛОГРАФІЇ В КИЇВСЬКІЙ ДИТЯЧІЙ АКАДЕМІЇ МИСТЕЦТВ

Тимків О.А.

РУКОПИСНІ САТИРИЧНІ ЖУРНАЛИ ПРЕСОВОЇ КВАРТИРИ УСС

Михалевич В.В. 
DOI 10.36074/23.10.2020.v1.18

\title{
РУКОПИСНІ САТИРИЧНІ ЖУРНАЛИ ПРЕСОВОЇ КВАРТИРИ УСС
}

\author{
Михалевич Віктор Вадимович \\ ORCID ID: 0000-0003-4847-5833
}

канд. культурології, доцент, доцент кафедри образотворчого мистецтва Київський університет імені Бориса Грінченка, Україна

Рукописні сатиричні журнали при Пресовій квартирі Українських Січових Стрільців (УСС) були важливою ідеологічною складовою добровольчого легіону. Сатиричні видання підіймали настрій та бойовий дух воїнів у важкі часи. Однак дані часописи мають не тільки історичну але й художню цінність, а творчість художників січовиків вплинула на розвиток української друкованої графріки.

Членами-засновниками Пресової кватири УСС були: Ю. Буцманюк, І. Іванець, О. Курилас, Ю. Назарак, Л. Перфецький, П. Холодний-молодший.

Наведемо художників УСС: М. Бринський, М. Гаврилко, М. Голубець, Л.Ґец, В. Залуцький, І. Іванець, Е. Козак, М. Крайнівський, О. Курилас, І. Кучмак, Л. Лепкий, Ю. Назарак, Л. Новіна-Розлуцький, В. Розумович, О. Сорохтей, В. Старчук, Я. Струхманчук, М. Талпаш, І. Ткачук, Є. Якимів та ін.

Більшість з вищезгаданих митців виступали ілюстраторами та дизайнерами стрілецьких сатиричних видань, та входили до штату Пресової квартири. Для багатьох стрільців-художників Пресової квартири праця у сатиричному жанрі стане визначальною упродовж усього життя.

Представимо хронологічну довідку стосовно сатиричних журналів УСС, що друкувалися в Пресовій квартирі УСС (у Коші), або в похідних умовах: «Новініада» (1915р.), 1 примірник, редактор - Р. Купчинський, художник - В. Розумович; «Самохотник» (1915 - 1918 рр.), близько 40 чисел, с. Пісочна, с. Камінка, с. Гнильче, с. Свистільники, засновник - М. Угрин-Безгрішний, видавець - Х. Тиндириндюк (псевдонім), редактор - А. Баб'юк, К. Кузьмович, А. Лотоцький, «Тото-Долото» (псевдонім), Самособою не-Руданський (псевдонім) та ін., карикатуристи: О. Курилас, Л. Ґец; «Молодий самохотник» (1916р.), м. Львів, карикатурист О. Курилас; «Самопал» (1916 р.), с. Пісочна, с. Свистільники, засновник - М. УгринБезгрішний, редактори: А. Баб'юк, А. Лотоцький, карикатурист - О. Курилас; «Бомба» (1916р.), 3 числа, с. Тудинка, карикатуристи: І. Іванець, Л. Лепкий, М. Оробець, О. Курилас, Л. Новіни-Розлуцький; «Усусу» (1916 -1917 рр.), 7 чисел, редактори: А. Баб'юк, Х. Вовкулака (псевдонім); «Червона Калина» (1917 р.), засновники: А. Лотоцький, В. Огоновський, Ю. Шкрумеляк, редактор - М. УгринБезгрішний, карикатуристи: О. Курилас, М. Гаврилко, П. Ковжун, І. Іванець; «Тифусна одноднівка» (1917р.), редактор - А. Баб’юк, карикатурист - О. Курилас; «Реп'яхи» (1918р.); «Республіканський самохотник» (1918-1919 рр.), м. Станіслав, карикатурист - О. Курилас; «Великодня Бомба» (1919 р.), с. Красів засновники та карикатуристи: І. Іванець, Л. Лепкий; «Їжак» (1919р.), м. Станіслав, редактор П. Ковжун; «Україна» (1920р.), м. Станіслав).

Можна ще навести приклади сатиричних видань УСС, які відрізняються цікавим графрічним наповненням та змістом.

Один з найпопулярніших часописів Пресової квартири УСС був «Самохотник» (рис. 1). 


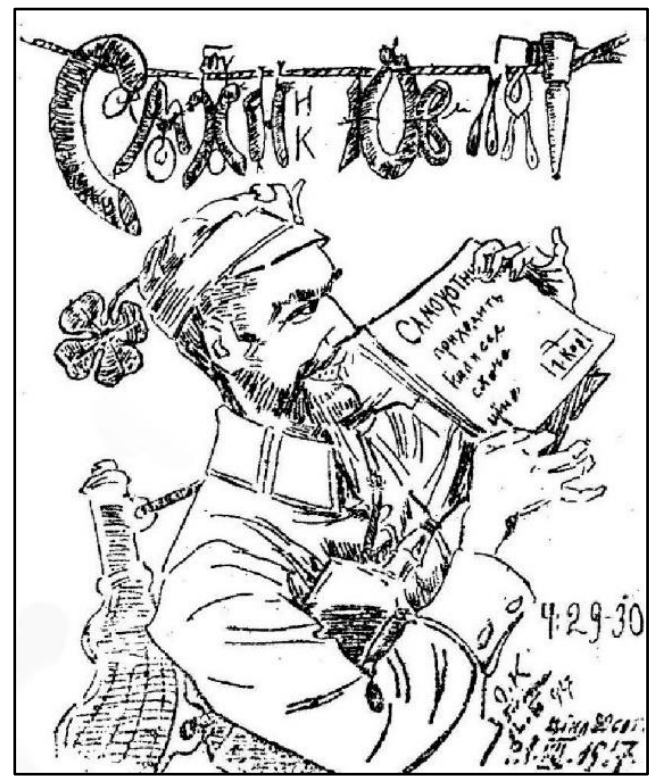

\section{Рис. 1. Обкладинка журналу «Самохотник», 1917 р. - Ч. 29-30, художник О. Курилас}

Журнал відрізняється значною кількістю ілюстративного матеріалу на тему кадрового життя стрільців, критикою начальства, подіями на фронті, політичного та соціального життя. Провідним художником даного часопису був О. Курилас, який оформлював видання «гострими» карикатурами та гротескними шаржами. Візуальні традиції журналу «Самохотник» Курилас пізніше використає в офрормленні іншого сатиричного часопису УСС «Республіканський самохотник».

Наступне сатиричне видання «Артистичної Горстки УСС» (літературномистецьке товариство січових стрільців) фронтовий журнал «Бомба», охоплював теми 3 життя стрілецтва та політики, критикував старшину. Видання мало 52 сторінки, великий формат, вміщувало багато ілюстрацій. На шпальтах «Бомби» поруч з текстом заверстані невеликі багатофрігурні композиції, що ілюструють реальні події та фракти життя усусів.

Польовий сатиричний часопис «Великодня бомба» 3 16-ти сторінок в техніці літографії став третім окремим тематичним числом «Бомби». Зазначимо, що сатиричні рисунки в даному журналі не пов'язані з текстом та розміщувалися на окремих шпальтах.

Зміст ілюстрацій часопису Пресової квартири «Самопал» розкривався за допомогою тексту, що мав специфічний стрілецький гумор і висміював взаємостосунки у військовому середовищі УСС.

Журнал стрільців-учнів «УСУС» гостро в сатиричній формі критикував діяльність тодішньої української політичної еліти, їхньої псевдоінтелігентності, та виносив на загал актуальні громадсько-суспільні проблеми.

Оригінальна назва наступного видання - «Тифусна одноднівка» говорить сама за себе. Автори видання таким чином іронізували над своїм «карантинним» становищем, коли в Коші спалахнула епідемія тифу.

У часописі «Червона Калина» присутні не тільки сатира і гумор, але й серйозні статті на тему української революції.

За результатами дослідження стає зрозуміло яке важливе значення займала сатирична преса у лавах УСС. Гумористичні рукописні часописи Пресової квартири УСС не обмежувалися лише пропагандиською функцією, а й відображали життя та побут січовиків засобами карикатури та шаржу. 


\section{Список використаних джерел:}

1. Кузьменко, Т. Г. (2017). Мистецько-художня творчість українських січових стрільців у контексті розвитку національної культури першої чверті XX століття. Питання культурології. (32), 89-110.

2. Лазарович, М. В. (2015). Видавничі проекти Українських січових стрільців під час Першої світової війни. Вісник Книжкової палати. (5), 32-36.

3. Рожак-Литвиненко, К. Б. (2017). Мистецьке угруповання українських січових стрільців: художники, традиції, жанрові та стильові особливості творів (дис. ... канд. мистецтвознавства). Львів. нац. акад. мистецтв. Львів. 
МАТЕРІАЛИ МІЖНАРОДНОЇ

НАУКОВОЇ КОНФЕРЕНЦІЇ

\section{«НАУКОВИЙ ПРОЦЕС ТА НАУКОВІ ПІДХОДИ: МЕТОДИКА ТА РЕАЛІЗАЦІЯ ДОСЛІДЖЕНЬ \\ 23 жовтня 2020 року Одеса, Україна}

\section{TOM 1}

Українською, боснійською та англійською мовами

Всі матеріали пройшли оглядове рецензування

Організаційний комітет не завжди поділяє позицію авторів

За точність викладеного матеріалу відповідальність несуть автори

Підписано до друку 23.10.2020. Формат 60×84/16. Папір офсетний. Гарнітура Arial. Цифрровий друк.

Умовно-друк. арк.8,25.

Тираж: 100 примірників.

Віддруковано з готового оригінал-макету.

Контактна інформація організаційного комітету:

21037, Україна, м. Вінниця, вул. Зодчих, 40, офріс 103

Міжнародний центр наукових досліджень

Телефони: +38098 1948380; +38098 1956755

E-mail: info@ukrlogos.in.ua

www.ukrlogos.in.ua| www.ojs.ukrlogos.in.ua

Видавець друкованих матеріалів: Друкарня ФОП Гуляєва В.М.

08700, Україна, м. Обухів, вул. Малишка, 5. E-mail: 5894939@gmail.com

Свідоцтво суб’єкта видавничої справи: ДК № 3909 від 02.11.2010 р. 